\title{
The Significance of a Nuclear Protein as a Moonlight Protein: Diagnostic and Therapeutic Potentials in Liver Transplantation
}

\author{
Shigeru Goto ${ }^{1,2^{*}}$, Toshiaki Nakano ${ }^{*}$, Li-Wen Hsu ${ }^{1}$, Kuei-Chen Chiang ${ }^{2}$, Yayoi Shimada ${ }^{2}$, Takeshi Goto ${ }^{2}$, Naoya Ohmori ${ }^{2}$, \\ Shuji Sato $^{2}$, Yuki Takaoaka ${ }^{5,4}$, Yasuo Magari ${ }^{5,4}$, Seiji Kawamoto ${ }^{6}$ and Chao-Long Chen ${ }^{1^{*}}$ \\ ${ }^{1}$ Liver Transplantaion Center, Kohsiung Chang Gung Memorial Hospital, Kaohsiung, Taiwan \\ ${ }^{2}$ Basic Medical Science of Nursing, Faculty of Nursing, Department of Nursing, Josai International University, Chiba, Japan \\ ${ }^{3}$ Fukuoka Institute of Occupational Health, Fukuoka, Japan \\ ${ }^{4}$ Clinical Medical Sciences, Chang Gung University College of Medicine, Kohsiung, Taiwan \\ ${ }^{5}$ Q-may Laboratory Corporation, Oita, Japan \\ ${ }^{6}$ Department of Molecular Biotechnology, Graduate School of Advanced Sciences of Matter, Hiroshima University, HigashiHiroshima, Japan
}

We have accumulated experimental evidences that a nuclear protein, histone $\mathrm{H1}$, and its immunosuppressive autoantibody $(\mathrm{Ab})$ are associated with post-transplant rejection and tolerance following liver transplantation [1-6]. In clinical setting, we have observed that serum level of histone $\mathrm{H} 1$ increased during rejection after liver transplantation while anti-histone $\mathrm{H} 1 \mathrm{Ab}$ was detected in liver transplant patients whose treatment with immunosuppressive drugs was withdrawn or reduced [7]

Protein moonlighting (or gene sharing) is a phenomenon by which a protein can perform more than one function [8] The detection of a protein in unexpected locations within cells, cell types, or tissues may suggest that a protein has a moonlighting function. In the nucleus, the original function of histone $\mathrm{H} 1$ has been well known as a DNA binding protein which binds to linker DNA between two nucleosomes and involves in the formation of higher order chromatin structure [9]. However, recent findings clearly demonstrated that extracellular histone $\mathrm{H} 1$ have completely different functions as so called, one of the "moonlight" proteins. Indeed, histone $\mathrm{H} 1$ is listed at two databases of moonlighting and multitasking proteins (http://wallace.uab.es/ multitask/ and http://www.moonlightingproteins.org/). Beyond the wall of nucleus, histone $\mathrm{H} 1$ translocates to mitochondria and acts as a mediator for apoptotic signal [10]. Furthermore, histone $\mathrm{H} 1$ expresses on the cell-surface of macrophages and acts as a receptor for thyroglobulin [11]. We and others found the extracellular nuclear proteins including histone $\mathrm{H} 1$ and high-mobility group box 1 (HMGB1) modulate immune responses in the course of immune cell activation and inflammation [12-31]. The trap of extracellular nuclear proteins after surgery may prevent not only rejection but also postoperative sepsis and disseminated intravascular coagulation (DIC) $[20,21,28,29,32]$.

As for immunological function of histone $\mathrm{H} 1$ as a moonlight protein, we have demonstrated that the maturation of dendritic cells (DCs) and subsequent $\mathrm{T}$ cell activation are enhanced by histone $\mathrm{H} 1$ [12]. Another nuclear protein, high-mobility group box 1 (HMGB1), is also involved in mechanisms of DC maturation [13]. Under a certain circumstance, nuclear proteins are secreted from nucleus of "dead" cells by necrosis, apoptosis or autophagy to systemic blood flow. These secreted nuclear proteins are currently being paid attention as damage-associated molecular patterns (DAMPs), signal/mediator or alarmins for cell death to spread inflammation in disseminated intravascular coagulation (DIC) and subsequently induce multiple organ failure (MOF) [22,25]. These results suggested that the detection of extracellular nuclear proteins has a possibility to be a novel diagnostic marker for sepsis, DIC or MOF after surgery as well as transplantation-related rejection. Recently, we have developed a kit to detect circulating histone $\mathrm{H} 1$, and are currently evaluating its

\section{Publication History:}

Received: January 31, 2017

Accepted: April 20, 2017

Published: April 22, 2017

\section{Keywords:}

Nuclear protein, Liver transplantation, Macrophages,

sensitivity and specificity for post-transplant liver allograft rejection in experimental (Figure 1) and clinical settings.

Regarding therapeutic application of anti-nuclear $\mathrm{Ab}$ in surgical field, our previous studies have demonstrated that either treatment of recipient rats with commercially available anti-histone $\mathrm{H} 1$ polyclonal $\mathrm{Ab}$ or immunization with calf thymus histone $\mathrm{H} 1$ could suppress acute rejection and prolong allograft survival in a rat heterotopic heart transplantation model $[1,34]$. We have also reported that the induction of autoimmune hepatitis, which produces anti-nuclear Abs, could overcome acute rejection and prolong liver allograft survival in a rat model of acute rejection after orthotopic liver transplantation (OLT) [16]. Immunologically, the blockade of histone H1 modulated DCs toward tolerogenic status, decreased the cytotoxicity of lymphokine activated killer and natural killer cells, and induced $\mathrm{CD} 4^{+} \mathrm{CD} 25^{+}$ regulatory $\mathrm{T}$ cells $[2,12]$. For further analysis of this mechanism, we generated an immunosuppressive monoclonal $\mathrm{Ab}$ against histone H1 (clone: 16G9) and determined a short peptide fragment, SSVLYGGPPSAA (SSV), that binds directly to $16 \mathrm{G} 9 \mathrm{mAb}$ (341). The binding of SSV to $16 \mathrm{G} 9 \mathrm{mAb}$ or serum of both tolerogeneic OLT rats and clinical drug-free OLT patients was inhibited by histone $\mathrm{H} 1$. Furthermore, SSV mAb or immunization of mice with SSV induced immunosuppression in serum, suggesting that SSV was an epitope responsible for the immunosuppressive activity of 16G9 mAb [34].

"Corresponding Author: Dr. Shigeru Goto, Liver Transplantation Center, Kaohsiung Chang Gung Memorial Hospital, 123 Ta-Pei Rd., Niao-Sung, Kaohsiung 833, Taiwan, E-mail: s-goto@athena.ocn.ne.jp,

"Corresponding Author: Dr. Toshiaki Nakano, Liver Transplantation Center Kaohsiung Chang Gung Memorial Hospital, 123 Ta-Pei Rd., Niao-Sung, Kaohsiung 833, Taiwan; E-mail: toshi.nakano@msa.hinet.net

"Corresponding Author: Dr. Chao-Long Chen, Liver Transplantation Center Kaohsiung Chang Gung Memorial Hospital, 123 Ta-Pei Rd., Niao-Sung, Kaohsiung 833, Taiwan; E-mail: clchen@cgmh.org.tw

Citation: Goto S, Nakano T, Hsu LW, Chiang KC, Shimada Y, et al. (2017) The Significance of a Nuclear Protein as a Moonlight Protein: Diagnostic and Therapeutic Potentials in Liver Transplantation. Int J Surg Surgical Porced 2: 116. doi: https://doi.org/10.15344/2456-4443/2017/117

Copyright: @ 2017 Goto et al. This is an open-access article distributed under the terms of the Creative Commons Attribution License, which permits unrestricted use, distribution, and reproduction in any medium, provided the original author and source are credited. 
Citation: Goto S, Nakano T, Hsu LW, Chiang KC, Shimada Y, et al. (2017) The Significance of a Nuclear Protein as a Moonlight Protein: Diagnostic and Therapeutic Potentials in Liver Transplantation. Int J Surg Surgical Porced 2: 116. doi: https://doi.org/10.15344/2456-4443/2017/117

Page 2 of 3

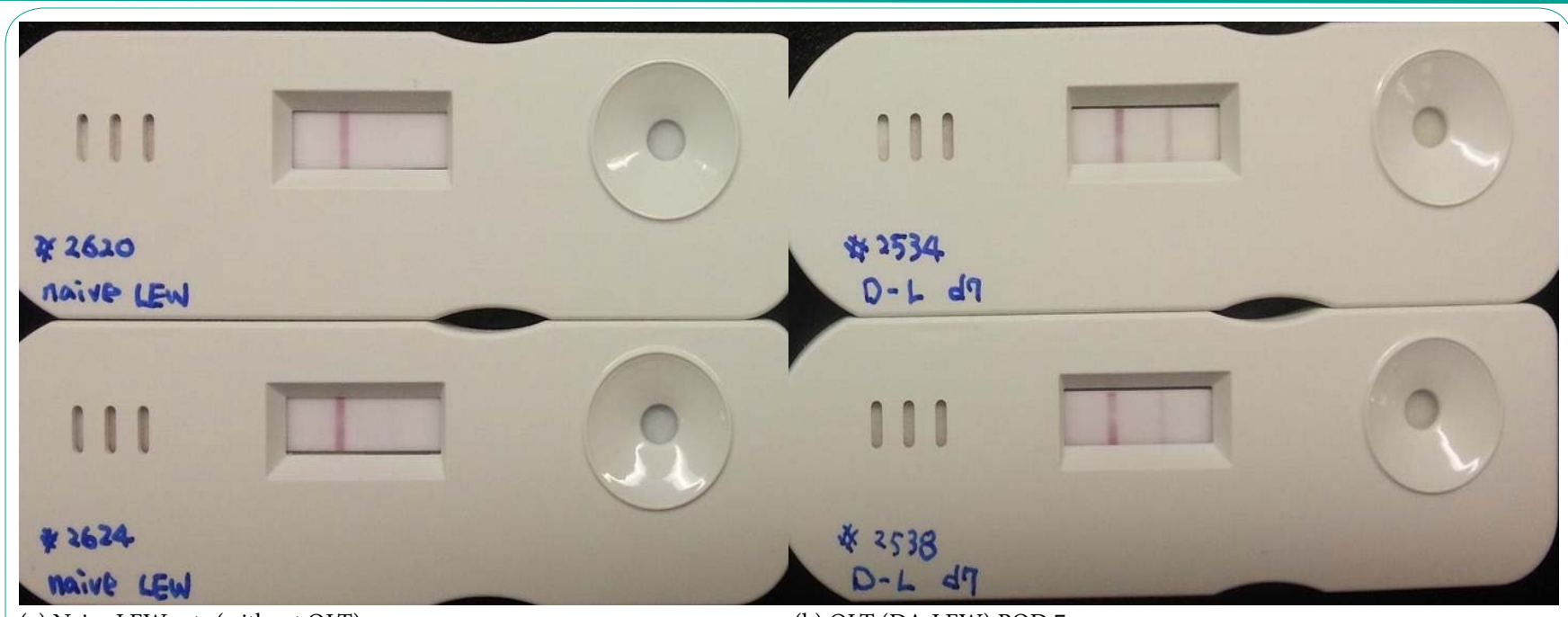

(a) Naive LEW rats (without OLT).

(b) OLT (DA-LEW) POD 7

Figure 1: Histone H1 detection kit (Q-may Laboratory Corporation, Oita, Japan).

In an acute rejection model of orthotopic rat liver transplantation (OLT; DA donor into LEW recipient) model, severe acute rejection was obseved on post-transplant day 7 in LEW (RT11) rats bearing DA (RT1a) livers. 100 microlitter of serm from naive LEW rats or OLT (DA-LEW) was applied to the kit. Histone H1 was not detected in serum of LEW rats while it was clearly detected in serum taken on post-operative day (POD) 7 after OLT(DA-LEW).

\begin{tabular}{|c|c|c|}
\hline (primary job, regular job) & $\begin{array}{c}\text { "MOON LIGHT" } \\
\text { (secondary job) }\end{array}$ \\
\hline Histone H1 & DNA binding & Release of histone H1 \\
\hline $\begin{array}{c}\text { Anti-histone H1 Ab } \\
\text { sSV mAb (our original) }\end{array}$ & $\begin{array}{c}\text { Rejection, Sepsis, } \\
\text { Inflamation, Allergy }\end{array}$ \\
\hline & Autoimmune diseases antibody & $\begin{array}{c}\text { Suppression of } \\
\text { rejection and induction } \\
\text { of tolerance }\end{array}$ \\
\hline & $\begin{array}{c}\text { Suppression of sepsis } \\
\text { Prevention of allergy }\end{array}$ \\
\hline
\end{tabular}

Table 1: Moonlighting function of histone h1 and its antibody.

Moonlighting function of histone $\mathrm{h} 1$ and its antibody was summarized in Table 1. A novel insight to the role of moonlighting nuclear proteins will allow us to establish a novel diagnostic and therapeutic strategy in post- operative complications as well as liver transplantation.

\section{Competing Interests}

The authors declare that they have no competing interests.

\section{Author Contributions}

Conceived and designed the experiments: TN,SG,SK, CLC. Performed the experiments: TN, KCC, LWH, YC.
Analyzed the data: TN, SG, TG, SS, NO.

Contributed reagents/materials/analysis tools: YT, YM

\section{Funding}

This work was supported in part by Grants from the National Science Council (NSC98-2320-B-182-029-MY3; NSC98-2314-B-182A-050MY2; NSC98-2314-B-182A-058-MY3) and the Chang Gung Memorial Hospital (CMRPD880011/2; CMRPD891671; CMRPG881081/2; CMRPG870901/2; CMRPG870051; CMRPG890721) of Taiwan. The funders had no role in study design, data collection and analysis, decision to publish, or preparation of the manuscript. 
Citation: Goto S, Nakano T, Hsu LW, Chiang KC, Shimada Y, et al. (2017) The Significance of a Nuclear Protein as a Moonlight Protein: Diagnostic and Therapeutic Potentials in Liver Transplantation. Int J Surg Surgical Porced 2: 116. doi: https://doi.org/10.15344/2456-4443/2017/117

Page 3 of 3

\section{References}

1. Nakano T, Kawamoto S, Lai CY Sasaki T, Aki T, et al. (2004) Liver transplantation-induced antihistone $\mathrm{H} 1$ autoantibodies suppress mixed lymphocyte reaction. Transplantation 77: 1595-1603

2. Hsu LW, Goto S, Nakano T, Lai CY, Kao YH, et al. (2005) The effects of anti-histone $\mathrm{H} 1$ antibody on immune cells responsible for rejection reaction. Molecular Immunology 42: 1155-1164.

3. Nakano T, Goto S, Lai CY, Hsu LW, Kao YH, et al. (2007) Experimental and clinical significance of anti-nuclear antibodies in liver transplantation. Transplantation 83: 1122-1125.

4. Shimada Y, Goto T, Kawamoto S, Kiso T, Katayama A, et al. (2008) Development of a two-step chromatography procedure that allows the purification of a high-purity anti-histone $\mathrm{H} 1$ monoclonal immunoglobulin $\mathrm{M}$ antibody with immunosuppressant activity. Biomed Chromatogr 22 : 13-19.

5. Katayama A, Kawamoto S, Yamanaka Y, Kiso T, Aki T, et al. (2008) Antihistone $\mathrm{H} 1$ autoantibody: An inducible immunosuppressive factor in liver transplantation. Animal Cell Technology: Basic \& Applied Aspects 15: 137-143.

6. Yamanaka Y, Kawamoto S, Katayama A, Kiso T, Aki T, et al. (2008) Anti-histone $\mathrm{H} 1$ autoantibody directly acts on $\mathrm{T}$ cells to exert its immunosuppressive activity. Animal Cell Technology: Basic \& Applied Aspects 15: 153-158.

7. Nakano T, Chen CL, Goto S (2013) Nuclear antigens and auto/ alloantibody responses: Friend or foe in transplant immunology. Clinical \& Developmental Immunology 2013: 267156.

8. Jeffery CJ (2003) Moonlighting proteins: old proteins learning new tricks. Trends Genet 19: 415-417.

9. Pereira SL, Reeve JN (1998) Histones and nucleosomes in Archaea and Eukarya: a comparative analysis. Extremophiles 2: 141-148.

10. Konishi A, Shimizu S, Hirota J, Takao T, Fan Y, et al. (2003) Involvement of histone H1.2 in apoptosis induced by DNA double-strand breaks. Cell 114: 673-688.

11. Jonathan D Gilthorpe, Fazal Oozeer1, Julia Nash, Margarita Calvo David LH Benn tt, Andrew Lumsden. (1998) Extracellular histone H1 is neurotoxic and drives a pro-inflammatory response in microglia. J Clin Invest 102: 283-293.

12. Hsu LW, Chen CL, Nakano T, Lai CY, Chiang KC, et al. (2008) The role of a nuclear protein, histone $\mathrm{H} 1$ on signaling pathways for the maturation of dendritic cells. Clin Exp Immunol 152: 576-584.

13. Dumitriu IE, Baruah P, Bianchi ME, Manfredi AA, Rovere-Querini P, et al (2005) Requirement of HMGB1 and RAGE for the maturation of human plasmacytoid dendritic cells. Eur J Immunol 35: 2184-2190.

14. Nakano T, Goto S, Lai CY, Hsu LW, Wong JL, et al. (2008) Involvement of autoimmunity against nuclear histone $\mathrm{H} 1$ in liver transplantation tolerance. Transplant Immunology 19: 87-92.

15. Kao YH, Jawan B, Goto S, Hung CT, Lin YC, et al. (2008) High-Mobility Group Box 1 Protein Activates Hepatic Stellate Cells In Vitro. Transplan Proc 40: 2704-2705.

16. Nakano T, Goto S, Lai CY, Hsu LW, Takaoka Y, et al. (2010) Immunological aspects and therapeutic significance of an auto-Ab against histone $\mathrm{H} 1$ in a rat model of Con A-induced hepatitis. Immunology 129: 547-555.

17. Goto S, Nakano T, Hsu LW, Chiang KC, Lai CY, et al. (2011) Autoimmunity and liver transplantation immunology. Current Trends in Immunology 12 : $1-11$.

18. Hsu LW, Goto S, Nakano T, Chen KD, Wang CC, et al. (2012) The effect of exogenous histone $\mathrm{H} 1$ on rat adipose-derived stem cell proliferation, migration, and osteogenic differentiation in vitro. J Cell Physiol 227: 3417-3425.

19. Palumbo R, Bianchi ME (2004) High mobility group box 1 protein, a cue for stem cell recruitment. Biochem Pharmacol 68: 1165-1170.

20. Takaoka Y, Kawamoto S, Katayama A, Nakano T, Yamanaka Y, et al. (2013) Unexpected $\mathrm{T}$ cell regulatory activity of anti-histone $\mathrm{H} 1$ autoantibody: Its mode of action in regulatory $\mathrm{T}$ cell-dependent and independent manners. Biochem Biophys Res Commun 431: 246-252.
21. Nakano T, Goto S, Lai CY, Hsu LW, Tseng HP, et al. (2013) Induction of antinuclear antibodies by de novo autoimmune hepatitis regulates alloimmune responses in rat liver transplantation. Clinical \& Developmental Immunology 2013: 413928 .

22. Wang $\mathrm{H}$, Bloom O, Zhang M, Vishnubhakat JM, Ombrellino M, et al. (1999) HMG-1 as a late mediator of endotoxin lethality in mice. Science 285: 248251.

23. Scaffidi P, Misteli T, Bianchi ME (2002) Release of chromatin protein HMGB1 by necrotic cells triggers inflammation. Nature 418: 191-195.

24. Harris HE, Raucci A (2006) Alarmin(g) news about danger: workshop on innate danger signals and HMGB1. EMBO Rep 7: 774-778.

25. Chavakis E, Hain A, Vinci M, Carmona G, Bianchi ME, et al. High-mobility group box 1 activates integrin-dependent homing of endothelial progenitor cells. Circ Res 100: 204-212.

26. Palumbo R, Sampaolesi M, De Marchis F, Tonlorenzi R, Colombetti S et al. (2004) Extracellular HMGB1, a signal of tissue damage, induces mesoangioblast migration and proliferation. J Cell Biol 164: 441-449.

27. Sadamura-Takenaka Y, Ito T, Noma S, Oyama Y, Yamada S, et al. (2014) HMGB1 Promotes the Development of Pulmonary Arterial Hypertension in Rats. PLoS ONE 9: e102482.

28. Nakahara M1, Ito T, Kawahara K, Yamamoto M, Nagasato T, et al. (2013) Recombinant Thrombomodulin Protects Mice against HistoneInducedLethal Thromboembolism. PLoS ONE 8: e75961.

29. Barnay-Verdier S, Fattoum L, Borde C, Kaveri S, Gibot S, et al. (2011) Emergence of autoantibodies to HMGB1 is associated with survival in patients with septic shock. Intensive Care Med 37: 957-962.

30. Hatada T, Wada H, Nobori T, Okabayashi K, Maruyama K, et al. (2005) Plasma concentrations and importance of High Mobility Group Box protein in the prognosis of organ failure in patients with disseminated intravascular coagulation. Thromb Haemost 94: 975-979.

31. Ito T, Kawahara K, Nakamura T, Yamada S, Nakamura T, et al. (2007) High-mobility group box 1 protein promotes development of microvascular thrombosis in rats. J Thromb Haemost 5: 109-116.

32. Kusano T, Chiang KC, Inomata M, Shimada Y, Ohmori N, et al. (2015) A novel anti-histone $\mathrm{H} 1$ monoclonal antibody, SSV monoclonal antibody, improves lung injury and survival in a mouse model of lipopolysaccharideinduced sepsis like syndrome. BioMed Research International 2015: 491649 .

33. Nakano T, Kamei R, Fujimura T, Takaoka Y, Hori A, et al. (2016) Impact of Histone $\mathrm{H} 1$ on the Progression of Allergic Rhinitis and Its Suppression by Neutralizing Antibody in Mice. PLoS One 11: e0153630.

34. Chiang KC, Shimada Y, Nakano T, Lai CY, Hsu LW, et al. (2009) A Novel Peptide Mimotope Identified as a Potential Immunosuppressive Vaccine for Organ Transplantation. Journal of Immunology 182: 4282-4288.

Int J Surg Surgical Porced 